\title{
Strategic Leadership Competencies: Evidence from the State of Qatar
}

\author{
Ali Mistarihi \\ Public Administration, Doha Institute for Graduate Studies, Doha, Qatar \\ Email: ali.mistarihi@dohainstutute.edu.qa
}

How to cite this paper: Mistarihi, A. (2021). Strategic Leadership Competencies: Evidence from the State of Qatar. Journal of Human Resource and Sustainability Studies, 9, 57-81.

https://doi.org/10.4236/jhrss.2021.91005

Received: February 1, 2021

Accepted: March 5, 2021

Published: March 8, 2021

Copyright $\odot 2021$ by author(s) and Scientific Research Publishing Inc. This work is licensed under the Creative Commons Attribution International License (CC BY 4.0).

http://creativecommons.org/licenses/by/4.0/

(c) (i) Open Access

\begin{abstract}
Leading in the age of more chaotic environments with newly emerging challenges and crises, such as the COVID-19 pandemic, demands special strategic leadership (SL) competencies. The main purpose of this study is to identify a specific SL set of competencies that should be available to strategic leaders and verify their availability to top-level public sector managers in the State of Qatar. An empirical analysis of 120 respondents revealed strategic leadership competency gaps among Qatari top-level managers. Further, top-level managers were not fully engaged in determining their organizations' strategic direction, did not exercise all SL behaviors, and only partially demonstrated strategic leadership characteristics, as they were more engaged in the operational activities of leadership. The study revealed that there are no statistically significant differences among respondents toward strategic leadership behaviors and characteristics attributed to their personal and occupational variables. The findings of this study will significantly contribute to enhancing and building strategic leadership competencies for top-level managers in the public sector organizations. A list of strategic leadership competencies that this research identified can serve as a frame of reference for designing strategic leadership training and development programs to enhance strategic leaders' capacities to manage their organizations more effectively.
\end{abstract}

\section{Keywords}

Strategic Leadership, Top-Level Managers, Competencies, Public Sector, The State of Qatar

\section{Introduction}

To achieve strategic goals, top-level executives of public sector organizations must possess and master certain competencies. These competencies, including 
knowledge and awareness, skills and abilities, behaviors, and other characteristics (or KSABOs thereafter), are assumed to be central to the management and leadership of efforts leading to the achievement of the national vision and strategic goals. Existing strategic leadership literature conforms to this assumption and suggests that top-level managers, as key decision and policy makers, play a significant role in strategy formulation and implementation relating to their organizations, and that this requires specific knowledge, skills, and leadership styles (Elenkov, Judge, \& Wright, 2005; Gupta \& Govindarajan, 1984; Hambrick \& Mason, 1984; Silva, Figueroa, \& González-Reinhart, 2007; Shao, Feng, \& Hu, 2017). However, the extant leadership literature has mainly focused on leadership competencies with a more generic label (e.g., the work of Heinen et al., 2019) and little research has been strategic-leadership-specific. Further, each "competency" has received a reasonable amount of attention in the leadership literature, but not in an all-inclusive list covering all competency areas, and seldom in the special context of high-stakes and deep-uncertainty environments that can make or break organizations (Schoemaker, Krupp, \& Howland, 2013)? This may be because of the "difficulty to imagine an all-inclusive list of competencies" (Guillot, 2003: 74). Thus, there is no universal consensus or final agreement among scholars on what exactly these competencies are. Yet, literature has shown that certain competencies are centrally associated with strategic leadership effectiveness (e.g., Guillot, 2003). Nevertheless, aligning these competencies to the strategic type of leadership has received very little scholarly attention.

Based on the description above, the aims of this study are to: 1) identify a list of relevant groupings of the most essential strategic leadership competencies (i.e., KSABOs) required for top-level managers to effectively manage and lead their organizations' strategic direction, 2) identify the extent to which these essential strategic leadership competencies (behaviors and other characteristics in particular) are available to the Qatari top-level public sector managers, and 3) give recommendations to public sector policy and decision makers to bridge top-level public sector managers' competency gaps and deficiencies, and thereby help them manage their organizations' strategic goals effectively.

\section{Theoretical Background and Previous Research}

\subsection{Strategic Leadership (SL)}

It is recognized that "the common usage of the term strategic is related to the concept of strategy-simply a plan of action for accomplishing a goal" (Guillot, 2003: 67). On the other hand, strategic leadership is defined as "the ability of an experienced, senior leader who has wisdom and vision to create and execute plans and make consequential decisions in the volatile, uncertain, complex and ambiguous strategic environment" (Guillot, 2003: 68). Remarkably, an early citation on strategic leadership was the work of Hosmer (1982). The researcher noted that a leader must constantly consider the organizational strategy in rela- 
tion to the external environment, and that leadership theories did not capture this reality. Since then, strategic leadership has been recognized as a distinct form of leadership and has started to attract interest and an identity.

To continue giving strategic leadership its eminent character and meaning, Norzailan, Yusof, and Othman (2016: 66) noted that SL is "about leadership activities at higher levels of a firm". These researchers believe that, unlike leadership at the operational level, which relies mainly on technical skills and is usually procedure-bound, strategic leadership requires a different mindset. Norzailan, Othman, and Ishizaki (2016) conform to this assumption and believe that while "general" leadership skills are still important, they are not sufficient for strategic leadership. Subscribing to this view, Gerras (2010: 28) suggested that, compared to a more "generic" form of leadership, "strategic leaders need to be able to envision long-range future requirements and to apply integrative thinking skills", among many other competencies that are specific to strategic leaders.

In explaining strategic leadership further, Boal and Hooijberg (2000) argued that the essence of strategic leadership involves learning and changing capacities and managerial wisdom. According to these researchers, strategic leadership integrates charismatic, transformational, and visionary leadership theories, adding to them the concepts of social intelligence. Similarly, Sebnem et al. (2011) viewed strategic leadership as a "three-dimensional" concept: charismatic, transformational, and visionary. In the same vein, Adair (2009) conceptualized leadership into three layers: the small team level with a given task(s); the operational level with several team leaders; and the strategic level of a whole organization. Agyepong et al. (2018) and Guillot (2003) expanded the boundaries of the environment in which strategic leaders work, to include the national, sub-national, and international levels. The work of Agyepong et al. (2018), for example, demonstrated that strategic leadership could be practiced at the national, sub-national or international agency levels, involving the ability to make decisions, communicate vision, develop structures and processes, control systems and manage multiple constituencies in a participatory leadership environment. Closely enough, and reflecting on the military environment, Guillot (2003) identified four distinct, interrelated parts of strategic leadership: the national security, domestic, military, and international environments (see Figure 1). For the author, strategic leaders usually work within both political and military environments, hence, cannot separate these four components, especially when they are dealing with issues relating to the national level.

As previously noted, the literature on strategic leadership is still in its early stage of development. Specifically, very little empirical research has been conducted to capture and verify the full range of competencies required for strategic leaders to lead effectively. Nevertheless, a few attempts have been made to address certain competencies that are viewed as essential to strategic leadership performance. Coban, Ozdemir, and Pisapia (2019), for example, have examined the relationship between the strategic leadership attitudes of top-level managers at the Ministry of National Education (MoNE) in Turkey and their competencies 


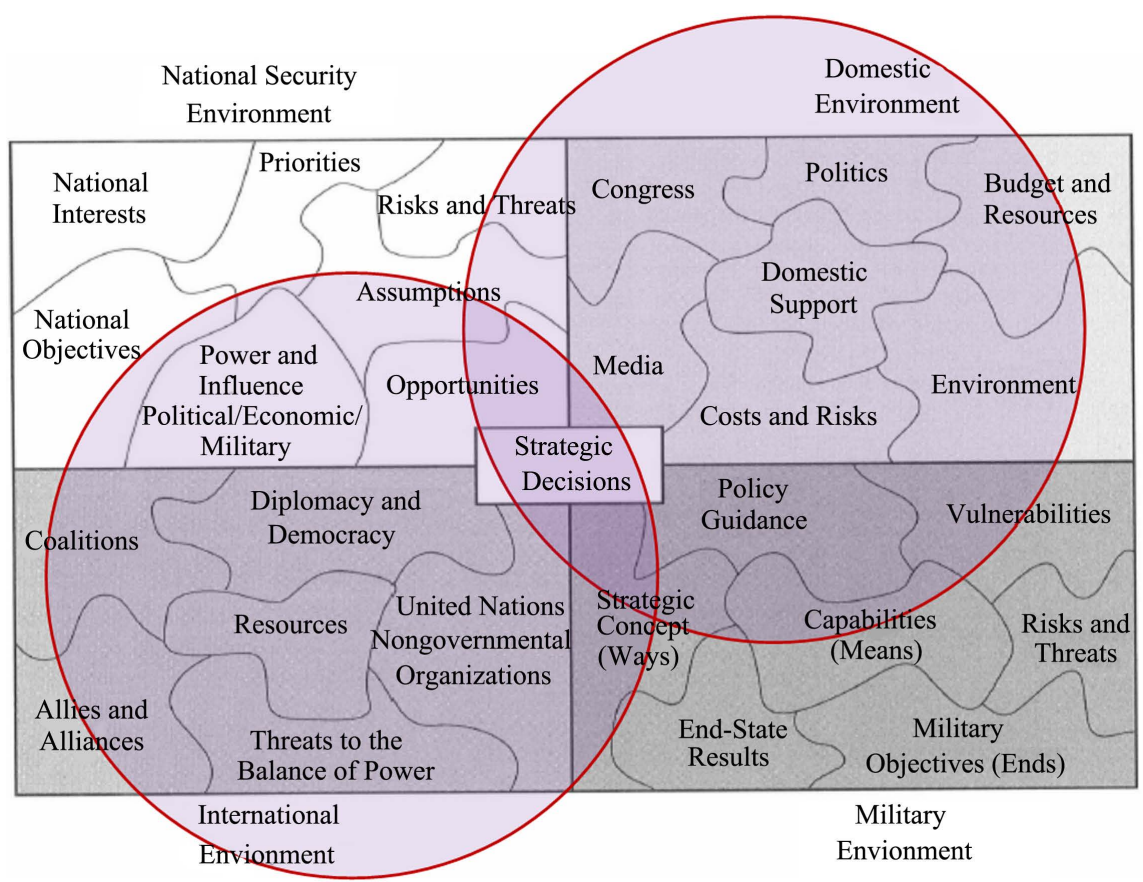

Figure 1. Four distinct, interrelated parts of strategic leadership (Adopted from Guillot, 2003: p. 69).

for managing organizational change, and found a highly positive relationship between the two variables. Similarly, a study conducted by Irtaimeh (2018) in the Jordanian context found that strategic leadership competencies (including dimensions of strategic thinking competencies and leadership competencies) have a significant impact on core competencies (team working, empowerment, communication, and influence).

In the Zimbabwean context, a study conducted by Mapetere et al. (2012) revealed that relatively low leadership involvement in strategy implementation and the lack of a strategic, well-articulated vision and communication led to limited strategy success. Maarten and Mikhail (2010) have also examined the potentials for strategic success in global firms working in Russia through the building of strategic leadership competencies. The findings support the importance of conducting a strategic Leadership Growth Profile (LGP) analysis of the anticipated strategic managers, as this was linked to strategic success.

In recognition of the importance of strategic leaders having certain skills and characteristics, the results of the study conducted by Hirschi and Jones (2009) showed that national culture, competitiveness, and market development affect strategic leadership and that the characteristics and skills of strategic leaders play a crucial role in enabling them to see the big picture ahead. Seeing the big picture, however, is only part of the story in strategic leadership, as strategic leaders must also be adaptive in reacting to environmental shifts. Research by Schoemaker, Krupp, and Howland (2013), and based on a survey of more than 20,000 executives, confirmed this assumption and identified six skills that, when mastered and used, allow leaders to think strategically and navigate the unknown ef- 
fectively. These are the abilities to anticipate, challenge, interpret, decide, align, and learn.

Notably, substantial challenges that the 21st century has brought to contemporary organizations, such as building people's capacities and understanding and rapidly changing technological advancements have created a need for different forms of leaders-i.e., strategic leaders (Irtaimeh, 2018). In theory, although the concept has recently gained more attention, it is still considered a relatively under-researched area.

\subsection{Strategic Leadership "Competencies”}

In attempting to define the term "competency", Gerras (2010: 28)" stated that "competencies are the knowledge, skills, attributes, and capacities that enable a leader to perform his [her] required tasks". According to the researcher, "what typically distinguishes a competency from a trait [for example] is the understanding that competencies can be developed and significantly improved for most individuals" through education and by reflective experience. For Gerras (2010: 28), "the major categories of leadership competencies consist of conceptual, technical, and interpersonal".

While there is no universally agreed-upon definition of the concept of "competency", Javidan (1998) attempted to establish differences among "core competency", "competency", "capability", and "resources" in strategic management, in a hierarchical order, based on their difficulty and value. Javidan's (1998) classification is an attempt to create a "universal understanding" of these concepts (Figure 2).

As contemporary organizations become more networked and have become more involved and engaged in sophisticated governance arrangements and actions, strategic leadership competencies, in particular, appear to be at the core of policy makers' attention and focus. That is simply because SLs demand special, untraditional management methods and competencies in making decisions, developing flexible structures, enabling and inspiring people, communicating future vision, and managing multiple and networked constituencies (Ireland \& Hitt, 1999; Bolden, 2011; Bass, 2007). Norzailan, Yusof, and Othman (2016) confirmed that strategic leaders, to be effective in their role, must have a certain predisposition and a set of key competencies.

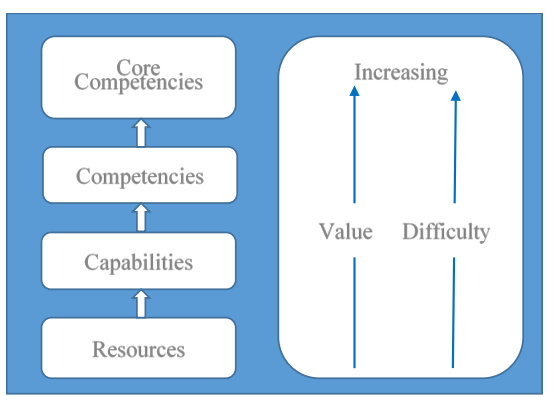

Figure 2. The competency hierarchy (Javidan, 1998). 
It is widely acknowledged that the extant literature on leadership has addressed "leadership" competencies in a more general term. Very little scholarly research has addressed "strategic leadership competencies" as such (see, for example, Weiler \& Dohlen, 2019; Ruben, 2019; Fasial \& Ayub, 2018). Closely enough, few attempts were made to introduce the concept of "strategic thinking competency", with little insight into what it takes to become a strategic thinker (Norzailan, Yusof, \& Othman, 2016; Farazmand, 2007). All the same, endeavors to conceptualize the concept of "strategic leadership competency" in the world of academic literature are still in progress (Fairholm \& Fairholm, 2009). This has resulted in a lack of theoretical understanding, leaving little guidance for strategic leaders (Liedtka \& Rosenblum, 1998).

The current research proposes that strategic leadership competencies include knowledge and awareness, skills and abilities, behaviors, and other characteristics (KSABOs). For purposes of this research, we also distinguish between those competencies that can easily be assessed by others due to their obtrusive observability nature, on the one hand, and those competencies that are unobtrusively observable by others and that can mainly be assessed by the SLs themselves, on the other hand (Figure 3). In particular, the obtrusively observable competencies (e.g. behaviors and characteristics) have been targeted for empirical testing in this research, as we used middle-level managers to judge the availability of these competencies to their top-level managers.

\subsection{Knowledge and Awareness Competencies}

Leading the strategic direction of an organization requires leaders who have a "bird's eye view" so that they can read the organization's external environment as well as internal capabilities (Norzailan, Yusof, \& Othman, 2016; Vera \& Crossan, 2004). In a similar view, Goldman (2012) suggested that strategic leaders should have a good understanding of the external environment so that they can deal with the changes, challenges, and discontinuities that emerge from time to time.

Sotarauta (2005) and Huang (2009) stressed the importance of having strategic thinking and strategic planning skills and knowledge for the strategic leader to perform effectively. To help to determine specific strategy weights and utilizing the balanced scorecard (BSC) framework developed by Kaplan and Norton

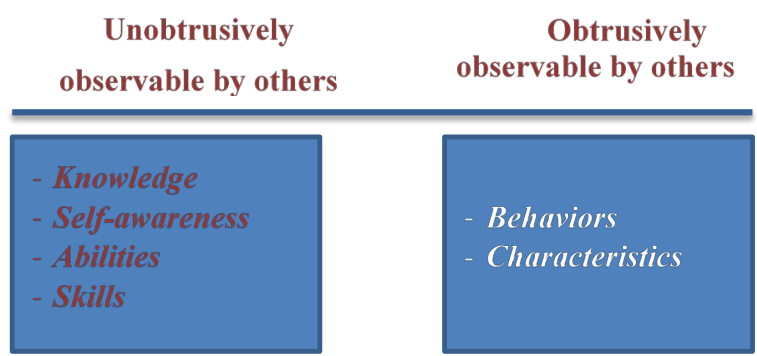

Figure 3. Unobtrusively-obtrusively observable strategic competencies suggested for this study. 
(1992), as well as using key performance indicators (KPIs), Huang (2009) proposed an integrated view of overall organizational performance as a powerful tool for strategic planning. The idea is to place more emphasis on learning and growth, internal process, and customer and financial performance in the context of strategic leadership, taking into account both financial and non-financial aspects.

In distinguishing between innovative thinking and strategic thinking, Deshler (2018) agreed that a strategic leader must understand and recognize themes, trends, and implications, and envision big ideas and their exact implications in real-life situations. Adding to this, Guillot (2003) suggested that strategic leaders must be culturally sensitive. Table 1 presents strategic leadership competencies relating to knowledge and awareness as suggested by scholars in the field.

\subsection{Skills and Abilities Competencies}

For strategic leaders to be effective in their roles, Norzailan, Yusof, and Othman (2016: 66) proposed three key competencies that they must have. These are "strategic thinking skills (to be able to think out of the box [see also, Mintzberg, 1994], skills in managing politics (to deal with the key coalitions and stakeholders involved in the strategizing process) and change management) to be able to realign internal capabilities to support the new strategy)". Sotarauta (2005) confirmed that strategic leaders must have strategic thinking and planning skills. In this regard, Sotarauta (2005: 69) added, "strategic leaders should have: 1) the ability to define strategies and visions, 2) the ability to transform these visions into focused strategies and action, 3) the ability to transform crisis situations into something constructive, 4) the ability to launch, manage and lead processes persistently in different phases, 5) the ability to find correct timing for development work and seize the competitive advantage by being a pioneer, and 6) the ability to achieve big objectives".

Table 1. Summary of strategic leadership competencies relating to knowledge and awareness as suggested by scholars in the field.

\begin{tabular}{lc}
\multicolumn{1}{c}{ Competency } & Reference in literature \\
\hline \multicolumn{1}{c}{ Knowledge and awareness (Strategic leaders should...) } \\
\hline $\begin{array}{l}\text { read the organization's external and internal } \\
\text { environments precisely }\end{array}$ & $\begin{array}{c}\text { Norzailan, Yusof, \& Othman (2016); } \\
\text { Vera \& Crossan (2004) }\end{array}$ \\
\hline $\begin{array}{l}\text { know how to deal with challenges emerging from } \\
\text { the external environment }\end{array}$ & Goldman (2012) \\
\hline $\begin{array}{l}\text { data applications } \\
\text { envision big ideas and their implications }\end{array}$ & Deshler (2018) \\
\hline know about strategic planning processes, evaluation, \\
and requirements
\end{tabular}


In their endeavor to distinguish between successful and less successful leaders, Pisapia, Reyes-Guerra, and Coukos-Semmel (2005) identified three cognitive processes (or skills) associated with strategic thinking. These skills are systems thinking skill ("the ability to see systems holistically by understanding the properties, forces, patterns and interrelationships that shape the behaviors of the systems which provides options for actions", p. 48), reframing skill ("the ability to switch attention across multiple perspectives, frames, mental models and paradigms in order to generate new insights and options for actions", p. 52), and reflecting skill ("the ability to weave logical and rational thinking through the use of perceptions, experience and information to make [a] judgment”, p. 56). Likewise, Goldman et al. (2015) confirmed that strategic leaders must be able to connect and synthesize ideas. Schoemaker, Krupp, and Howland (2013) identified six skills that, when mastered and used at one time, allow leaders to think strategically and navigate the unknown effectively. These skills are the abilities to anticipate, challenge, interpret, decide, align, and learn. Graetz (2012: 457) confirmed that strategic leaders must use "imagination to assess and interpret the cues from the external environment and deciding how to respond to them". For Stigter and Cooper (2015) and Appiah-Adu and Aming (2016), signs of change are not very clear and require sense-making ability on the part of the strategic leader. Table 2 presents strategic leadership competencies relating to skills and abilities as suggested by scholars in the field that should be available to strategic leaders to manage effectively.

Table 2. Summary of strategic leadership competencies relating to skills and abilities as suggested by scholars in the field.

\begin{tabular}{|c|c|}
\hline Competency & Reference in literature \\
\hline \multicolumn{2}{|c|}{ Skills \& abilities (Strategic leaders should have...) } \\
\hline $\begin{array}{l}\text { the ability to imagine, anticipate, assess, } \\
\text { interpret, and challenge environmental changes; } \\
\text { decide upon and align strategies in dealing } \\
\text { with them; learn from their experiences; } \\
\text { and have sense-making ability }\end{array}$ & $\begin{array}{c}\text { Schoemaker, Krupp, \& Howland (2013); } \\
\text { Graetz (2012); } \\
\text { Stigter \& Cooper (2015); } \\
\text { Appiah-Adu \& Aming (2016) }\end{array}$ \\
\hline $\begin{array}{l}\text { the ability to define strategies and visions; } \\
\text { transform visions into strategies and action; } \\
\text { transform crisis into something constructive; } \\
\text { launch, manage, and lead change processes; find } \\
\text { the correct timing for change and } \\
\text { development; and achieve big objectives }\end{array}$ & Sotarauta (2005); Agyepong et al. (2018) \\
\hline - the ability to connect and synthesize ideas & Goldman et al. (2015) \\
\hline $\begin{array}{l}\text { the ability to think and plan strategically, } \\
\text { and manage politics and change }\end{array}$ & $\begin{array}{l}\text { Norzailan, Yusof, \& Othman (2016); } \\
\text { Mintzberg (1994); } \\
\text { Sotarauta (2005); } \\
\text { Farazmand (2007) }\end{array}$ \\
\hline $\begin{array}{l}\text { - the ability to think systematically, and have } \\
\text { reframing and reflecting skills }\end{array}$ & $\begin{array}{l}\text { Pisapia, Reyes-Guerra, } \\
\text { \& Coukos-Semmel (2005) }\end{array}$ \\
\hline
\end{tabular}

Source: Drawn from multiple sources. 


\section{5. "Practiced" Behavioral Competencies}

Guillot (2003) asserted that certain "behaviors" relating to strategic leadership can be learned, as strategic leaders are made, not born. The researcher argued that strategic leaders must anticipate, lead, and foster change, seek novel ideas and foster creativity, act effectively in times of chaos, critically analyze their own thinking, build effective teams, negotiate effectively, assume the role of mentor and teacher, and invest in developing other leaders.

In his research, Shao (2019) found that "idealized influence" and "inspirational motivation" behaviors in transformational leadership are significant behavioral drivers of business strategic alignment. Beer and Eisenstat (2000) stressed the importance of demonstrating six effective strategic leadership practices in strategy formulation and implementation. These are: 1) a top-down direction with upward influence; 2) clear strategies; 3) an effective top management team; 4) open vertical communication; 5) effective coordination; and 6) the allocation of clear accountability and authority to middle management. Likewise, Bass (2007: 42) offered nine "effective strategic leadership practices". These being: "1) focusing attention on outcomes and processes; 2) seeking to acquire and leverage knowledge; 3) fostering learning, and creativity; 4) improving workflows by attention to relationships; 5) anticipating internal and external environmental changes; 6) maintaining a global mindset; 7) meeting the diversity of the interests of the multiple stakeholders; 8) building for the long-term while meeting short-term needs; and 9) developing human capital". Similarly, Ireland and Hitt (1999) proposed six components of effective strategic leadership in which strategic leaders must get involved, including: 1) determining the organization's purpose or vision; 2) exploiting and maintaining core competencies; 3) developing human capital; 4) sustaining an effective organizational culture; 5) emphasizing ethical practices; and 6) establishing balanced organizational controls. Building on the work of Hitt, Ireland, and Hoskisson (1995), Hagen, Hassan, and Amin (1998) examined the six core competencies developed by the previous researchers and found that these competencies were present to the respondents (in order of importance) as follows: 1) determining strategic direction; 2) developing human capital; 3) exploiting and maintaining core competencies; 4) sustaining an effective corporate culture; 5) emphasizing ethical practices; and 6) establishing strategic controls. Table 3 presents strategic leadership competencies relating to strategic leaders' behaviors as suggested by scholars in the field.

\subsection{Characteristics of Strategic Leaders}

The extant literature on strategic leadership stressed that, for strategic leaders to perform successfully, they must possess certain characteristics, qualities, traits, and attitudes. Schoemaker, Krupp, and Howland (2013), for example, suggested that strategic leaders should be resolute and flexible, and show persistence in the face of setbacks. Norzailan, Othman, and Ishizaki (2016) confirmed that strategic leaders must be persistent and resilient in order to face difficulties and failures 
Table 3. Summary of strategic leadership behaviors as suggested by scholars in the field.

\begin{tabular}{ll}
\hline \multicolumn{1}{c}{ Competency } & \multicolumn{1}{c}{ Reference in literature } \\
\hline \multicolumn{1}{c}{ Behaviors (Strategic leaders should...) } \\
\hline $\begin{array}{l}\text { demonstrate idealized influence and inspirational } \\
\text { motivation behaviors; and anticipate, lead, and } \\
\text { foster change }\end{array}$ & Shao (2019); Guillot (2003) \\
\hline $\begin{array}{l}\text { give top-down clear directions and facilitate upward } \\
\text { communication; formulate clear strategies; support } \\
\text { effective coordination; and allocate clear accountability } \\
\text { and authority to middle management }\end{array}$ & Beer \& Eisenstat (2000) \\
\hline $\begin{array}{l}\text { focus attention on outcomes and processes; seek and } \\
\text { leverage knowledge; foster learning and creativity; } \\
\text { improve workflows by paying attention to relationships; } \\
\text { maintain a global mindset; meet the interests of } \\
\text { multiple stakeholders; work on long-term goals while } \\
\text { meeting short-term needs; and develop human capital }\end{array}$ & \\
\hline $\begin{array}{l}\text { determine the organization's purpose or vision and } \\
\text { strategic direction; exploit and maintain core } \\
\text { competencies; develop human capital; sustain an } \\
\text { effective organizational culture; emphasize ethical } \\
\text { practices; and establish balanced controls }\end{array}$ \\
$\begin{array}{l}\text { seek novel ideas and foster creativity; effectively act in } \\
\text { times of chaos; critically analyze one's own thinking; } \\
\text { build effective teams; negotiate effectively; assume the } \\
\text { role of mentor and teacher; and invest in developing } \\
\text { other leaders }\end{array}$ \\
$\begin{array}{l}\text { Ireland \& Hitt (1999); Hitt, Irelan, } \\
\text { \& Hoskisson (1995); Hagen, Hassan, }\end{array}$ \\
\& Amin (1998)
\end{tabular}

Source: Drawn from multiple sources.

and deal with uncertainties. Likewise, Sotarauta (2005) argued that the knowledge economy requires brave and visionary leaders who can deal with new emergent innovative networks to get things done.

In the military sector, Wong et al. (2003) identified six meta-competencies for a strategic leader, including identity, mental agility, cross-cultural savvy, interpersonal maturity, world-class warrior, and professional astuteness. In a similar vein, Guillot (2003) proposed a "must-have" list of competencies that seem essential for strategic leaders to have. To the researcher, leaders must be proactive in responding to the strategic environment as vision makers, be aware of cultural sensitivity, and be transformational in inspiring people toward shared goals and values. In fact, strategic leaders serve as champions of innovation, adaptation, and the incubation of new creative ideas (Bass, 2007). Also, close to Guillot (2003), Coban, Ozdemir, and Pisapia (2019) conformed to the view that strategic leaders should have a vision in terms of the direction in which employees should go.

Marshall (2019) saw passion, ambition, and commitment to shared values as key success qualities of strategic leaders. Marshall'(2019) also believed that trust, respect, and agility are qualities necessary for strategic leaders to help their organizations move forward strategically. Further, the researcher viewed data 
analysis, agility and creativity, horizon scanning, diversity and inclusivity, and E4 leadership (i.e., be energized; empowered and empower others; be engaged and engage others) as essential for today's strategic leaders and those of the future. Agyepong et al. (2018: ii35) also confirmed that strategic leaders should have certain competency requirements, such as "providing vision and inspiration for the organization, core personal values and character qualities such as integrity and trustworthiness, [...] adapting to situations and context and creating and maintaining effective change and systems". Sashkin (1992) added cognitive capacity, self-efficacy, and the power motive as personal requirements for competence in strategic leadership. Table 4 presents strategic leadership competencies relating to "leaders' characteristics" as suggested by scholars in the field.

As previously noted, for purposes of this research, we distinguish between those competencies that can easily be assessed by others due to their obtrusive observability nature, on the one hand, and those competencies that are unobtrusively observable by others and that can mainly be assessed by the SLs themselves, on the other hand (Figure 3). In particular, the obtrusively observable competencies (e.g. behaviors and characteristics) have been targeted for empirical testing in this research, as we used middle-level managers to judge the availability of these competencies to their top-level managers.

Based on the foregoing discussion, this study hypothesizes that:

Table 4. Summary of strategic leadership characteristics as suggested by scholars in the field.

\begin{tabular}{|c|c|}
\hline Competency & Reference in literature \\
\hline \multicolumn{2}{|c|}{ SLs' characteristics (Strategic leaders should...) } \\
\hline $\begin{array}{l}\text { be inclusive, resolute, and flexible, and show } \\
\text { persistence and resilience in facing difficulties } \\
\text { and uncertainties }\end{array}$ & $\begin{array}{c}\text { Schoemaker, Krupp, \& Howland (2013); } \\
\text { Norzailan, Othman, \& Ishizaki (2016); } \\
\text { Marshall (2019) }\end{array}$ \\
\hline $\begin{array}{l}\text { - be brave; be visionary; act as champions of } \\
\text { innovation; and adapt and incubate new ideas }\end{array}$ & $\begin{array}{l}\text { Sotarauta (2005); Coban, Ozdemir, \& } \\
\text { Pisapia (2019); Bass (2007) }\end{array}$ \\
\hline $\begin{array}{l}\text { have mental agility and creativity; be } \\
\text { cross-culturally savvy; have interpersonal maturity; } \\
\text { be world-class warriors; and have professional } \\
\text { astuteness }\end{array}$ & Wong et al. (2003) \\
\hline - be proactive & Guillot (2003) \\
\hline $\begin{array}{l}\text { be energized; be empowered and empower others; } \\
\text { be engaged and engage others }\end{array}$ & Marshall (2019) \\
\hline $\begin{array}{l}\text { be trustworthy and respectful; have integrity, } \\
\text { agility, passion, and ambition; and have } \\
\text { commitment to shared values }\end{array}$ & $\begin{array}{l}\text { Marshall (2019); } \\
\text { Agyepong et al. (2018) }\end{array}$ \\
\hline $\begin{array}{l}\text { - have cognitive capacity, self-efficacy, and the } \\
\text { power motive }\end{array}$ & Sashkin (1992) \\
\hline
\end{tabular}

Source: Drawn from multiple sources. 
H1: There is a high degree of agreement among the study respondents that their top-level managers exhibit strategic leadership behaviors in their positive values.

H2: There is a high degree of agreement among the study respondents that their top-level managers have strategic leadership characteristics in their positive values.

H3: There are no statistically significant differences (at the significance level of $a \leq 0.05$ ) among respondents about the study concepts (strategic leadership behaviors) and (strategic leadership characteristics) attributed to their personal and occupational variables.

\section{Research Methodology}

\subsection{Research Design}

This study follows four research steps. First, and based on the literature reviewed on the topic, we identified the competencies that are essentially required for strategic leaders to effectively manage and lead their organizations strategic direction. Second, a questionnaire survey was specifically designed for this study to measure the availability level of these competencies (behaviors and characteristics in particular) to the Qatari public sector top-level managers. Third, samples were collected using Qualtrics Web survey system. Fourth, data were collected and then analyzed using SPSS package.

\subsection{Instrument/Measurement}

Based on a review of the literature on the topic, a quantitative research design was employed. To do so, a pre-tested, self-administered questionnaire survey was designed particularly for this study to collect data from the target population. This custom-tailored questionnaire survey was used to target the views of middle-level managers in Qatari public sector organizations on the level of certain strategic leadership competencies available to their top-level managers. The survey was ethically pre-approved and participation was voluntary and completely anonymous.

A 5-point Likert scale was used in the survey and given the following values: " 1 = strongly disagree", " $2=$ disagree", " $3=$ not sure”, “ $4=$ agree”, and $5=$ strongly agree". Lower scores are associated with a lesser extent of availability of strategic leadership practices. In this study, mean values ranging between 3.19 and 3.34 were considered neutral values. Therefore, values greater than 3.34 were considered an overall approval, while values below 3.19 indicated a disapproval response.

The survey consisted of three parts. Part I included personal information (gender, age, and level of education) and occupational information (years of service and job level). Part II displayed strategic leadership behaviors practiced by the target population and consisted of 30 items. Part III displayed characteristics of strategic leaders and consisted of 20 items. 


\subsection{Population and Sampling}

The survey for this study was randomly distributed to 152 respondents representing middle-level employees working in different Qatari public sector organizations, using the electronic Qualtrics platform. A total of 129 participants filled out the questionnaire, creating a response rate of $85 \%$; of these, 120 were valid for analysis. Although the respondents could be categorized into strata or clusters depending on the type of public organization, this was not a wise choice due to the heterogeneity of the data and because most questions treated the sample as a whole, without subdividing it depending on strata or clusters. Therefore, the sampling method chosen was simple random sampling.

\subsection{Validity and Reliability}

In determining the consistency of the instrument, the Cronbach's Alpha test was used to measure the reliability of the study dimensions (see Table 5). The overall Cronbach Alpha for all items in the research instrument was determined as 0.861 , which was detected as higher than the threshold value of 0.7 and proves that research scale was clearly understood by the participants and the question in the scale were not inaccurate, therefore, the research instrument was deemed very reliable.

\section{Study Findings and Discussion}

\section{Personal and Occupational Characteristics of Respondents}

A total of 120 employees completed the survey; about $53 \%$ of them were male respondents. Almost a half of the respondents (47.5\%) fall in the age group of 31 to 40 years old, $30 \%$ of them have had 16 to 20 years of experience, with $55 \%$ holding master's degrees, and most of them (60\%) are Division Heads. Personal and occupational factors are presented in Table 6.

\section{Validating the study hypotheses}

\section{Validating $H 1$ :}

This hypothesis states that there is a high degree of agreement among the study respondents that their top-level managers exhibit strategic leadership behaviors in their positive values.

Table 7 shows descriptive statistics of the respondents' degree of agreement on the availability of strategic leadership behaviors to Qatari top-level managers in their positive value. The overall mean for all items was 3.20, which means that respondents agreed that only certain SL behaviors were available to Qatari

Table 5. Reliability statistics.

\begin{tabular}{|c|c|c|}
\hline Factor & No. of Items & Cronbach alpha value \\
\hline SL Behaviors & 30 & 0.847 \\
\hline SL Characteristics & 20 & 0.875 \\
\hline \multicolumn{2}{|c|}{ Overall } & 0.861 \\
\hline
\end{tabular}


Table 6. Distribution of respondents according to their personal and occupational characteristics.

\begin{tabular}{|c|c|c|c|c|}
\hline & & Frequency & Percent & Valid Percent \\
\hline \multirow{3}{*}{ Gender } & Male & 64 & 53.0 & 53.0 \\
\hline & Female & 56 & 47.0 & 47.0 \\
\hline & Total & 120 & 100.0 & 100.0 \\
\hline \multirow{6}{*}{ Years of Service } & less than 5 years & 12 & 10.0 & 10.0 \\
\hline & $5-10$ years & 24 & 20.0 & 20.0 \\
\hline & $11-15$ years & 24 & 20.0 & 20.0 \\
\hline & 16 - 20 years & 36 & 30.0 & 30.0 \\
\hline & 21 years or more & 24 & 20.0 & 20.0 \\
\hline & Total & 120 & 100.0 & 100.0 \\
\hline \multirow{5}{*}{ Job Level } & division head & 72 & 60.0 & 60.0 \\
\hline & department head & 18 & 15.0 & 15.0 \\
\hline & main department head & 12 & 10.0 & 10.0 \\
\hline & consultant & 18 & 15.0 & 15.0 \\
\hline & Total & 120 & 100.0 & 100.0 \\
\hline \multirow{5}{*}{ Age } & $20-30$ & 15 & 12.5 & 12.5 \\
\hline & $31-40$ & 57 & 47.5 & 47.5 \\
\hline & $41-50$ & 45 & 37.5 & 37.5 \\
\hline & $51-60$ & 3 & 2.5 & 2.5 \\
\hline & Total & 120 & 100.0 & 100.0 \\
\hline \multirow{4}{*}{ Qualification } & bachelor & 42 & 35.0 & 35.0 \\
\hline & master & 66 & 55.0 & 55.0 \\
\hline & doctorate & 12 & 10.0 & 10.0 \\
\hline & Total & 120 & 100.0 & 100.0 \\
\hline
\end{tabular}

Table 7. Descriptive statistics of the respondents' degree of agreement on strategic leadership behaviors.

\begin{tabular}{|c|c|c|c|}
\hline & SL Behaviors of Qatari top-level managers & Mean & $\begin{array}{c}\text { Std. } \\
\text { Deviation }\end{array}$ \\
\hline 30 & engage stakeholders in setting out organization's strategic plans & 3.60 & 0.90 \\
\hline 23 & assume the role of mentor and teacher & 3.55 & 1.60 \\
\hline 16 & emphasize ethical practices & 3.48 & 1.20 \\
\hline 11 & meet the interests of multiple stakeholders & 3.45 & 0.81 \\
\hline 22 & negotiate effectively whenever needed & 3.43 & 1.11 \\
\hline 27 & $\begin{array}{l}\text { conduct a systematic performance evaluation on the progress of } \\
\text { achieving our strategic plans }\end{array}$ & 3.40 & 1.01 \\
\hline 29 & $\begin{array}{l}\text { establish partnerships and networks with communities, } \\
\text { the private sector, and other civil society organizations }\end{array}$ & 3.40 & 1.13 \\
\hline
\end{tabular}




\section{Continued}

\begin{tabular}{|c|c|c|c|}
\hline 4 & give clear top-down directions & 3.35 & 1.23 \\
\hline 7 & focus attention on outcomes & 3.35 & 1.19 \\
\hline 10 & maintain a global mindset & 3.28 & 1.01 \\
\hline 8 & foster organizational learning processes & 3.25 & 1.13 \\
\hline 19 & act effectively in the times of chaos & 3.25 & 1.01 \\
\hline 26 & $\begin{array}{l}\text { participate actively in national and international strategic } \\
\text { leadership discussions }\end{array}$ & 3.25 & 1.03 \\
\hline 21 & build effective teams & 3.23 & 1.21 \\
\hline 24 & sustain an effective organizational culture & 3.18 & 1.06 \\
\hline 25 & support research agendas on future strategic planning & 3.18 & 1.17 \\
\hline 9 & improve work flows by attention to relationships & 3.15 & 1.19 \\
\hline 14 & ensure developing human capital & 3.15 & 1.17 \\
\hline 28 & $\begin{array}{l}\text { design action plans for mobilizing public and political support for our } \\
\text { organization's programs and policies }\end{array}$ & 3.15 & 1.05 \\
\hline 12 & focus on long-term goals while meeting short-term needs & 3.14 & 1.03 \\
\hline 3 & lead and foster strategic change & 3.13 & 1.14 \\
\hline 6 & allocate clear accountability and authority to middle management & 3.13 & 1.18 \\
\hline 17 & establish balanced control systems & 3.13 & 1.11 \\
\hline 1 & demonstrate idealized influence & 3.05 & 1.18 \\
\hline 5 & ensure that bottom-up communication is kept open & 3.03 & 1.27 \\
\hline 18 & seek novel ideas and foster creativity & 3.03 & 1.21 \\
\hline 2 & demonstrate inspirational motivation behaviors & 2.98 & 1.10 \\
\hline 20 & critically analyze their own thinking & 2.93 & 1.07 \\
\hline 15 & invest in developing other leaders & 2.83 & 1.17 \\
\hline 13 & $\begin{array}{l}\text { determine our organization's mission, vision, } \\
\text { and national strategic direction }\end{array}$ & 2.63 & 1.13 \\
\hline & & 3.20 & 1.126 \\
\hline
\end{tabular}

top-level managers; yet responses have not shown high levels of agreement. Further, the standard deviation for all items was 1.126, which means that differences in the respondents' views about these items were relatively minimal. More specifically, the respondents agree that Qatari top-level managers engage stakeholders in setting their organizations' strategic plans (which achieved the highest level of agreement, with an average score of 3.6). They also consider multiple interests of the stakeholders, act as mentors to employees, emphasize ethical practices, negotiate effectively whenever needed, conduct systematic performance evaluations to achieve strategic plans, establish partnerships and networks with communities, private sector, and other civil society organizations, give clear top-down directions, and focus their attention on outcomes. At the same time, respondents tend to disagree on whether their top-level managers actually de- 
termine their organizations' mission, vision, and national strategic direction (which achieved the lowest level of agreement, with an average score of 2.63). They also disagree that their top-level managers invest in developing other leaders, critically analyze their own thinking, demonstrate inspirational motivation behaviors, seek novel ideas and foster creativity, ensure that bottom-up communication is kept open, and demonstrate idealized influence. In conclusion, hypothesis $\mathrm{H} 1$ was partially accepted.

Looking deeper into these results, it can be concluded that Qatari top-level managers are not fully engaged in determining their organizations' strategic direction and do not exercise all strategic leadership behaviors, particularly transformational leadership practices. Instead, they are more engaged in the operational activities of leadership. This finding corresponds well with Norzailan, Yusof, and Othman's (2016), Norzailan, Othman, and Ishizaki's (2016), and Gerras' (2010) belief that strategic leaders [should] engage in activities at the higher levels of the organization and must be able to envision long-range future requirements, while a "generic type" of leadership is usually practiced at the operational level which mainly relies on technical skills and is usually procedure-bound.

\section{Validating $H 2$ :}

This hypothesis states that there is a high degree of agreement among the study respondents that their top-level managers have strategic leadership characteristics in their positive values. Table 8 shows the descriptive statistics of the respondents' degree of agreement on strategic leadership characteristics. The overall mean for all items is 3.30, which means that respondents agreed that only certain SL characteristics were available to Qatari top-level managers. However, the responses do not show high levels of agreement. Further, the standard deviation for all items is 1.099, which means that the difference in the respondents' views about these items was relatively minimal. More specifically, the respondents agree that their top-level managers are respectful (which achieved the highest level of agreement, with an average score of 3.95), are committed to shared values, have integrity, have the passion to achieve strategic goals, and are ambitious. At the same time, respondents tend to disagree that they view their top-level managers as world-class warriors (which achieved the lowest level of agreement, with an average score of 2.93). They also disagree that their top-level managers act as champions of innovation, have mental agility and creativity, are visionary, and have a willingness to empower employees. In conclusion, hypothesis $\mathrm{H} 2$ was partially accepted.

Looking deeper into these results, it can be concluded that Qatari top-level managers partially demonstrate SL characteristics. These managers should be combatant commanders in the midst of the journey toward the future to move forward strategically and be champions of innovation and change. They must also be creative and visionary, and have the willingness to empower their employees. These findings conform well with Sotarauta' (2005), Bass's (2007), Coban, Ozdemir, and Pisapia's (2019), and Agyepong et al.'s (2018) proposition 
Table 8. Descriptive statistics of the respondents' degree of agreement on strategic leadership characteristics of Qatari top-level managers.

\begin{tabular}{|c|c|c|c|}
\hline & SL Characteristics of Qatari top-level managers & Mean & $\begin{array}{c}\text { Std. } \\
\text { Deviation }\end{array}$ \\
\hline 16 & are respectful & 3.95 & 0.60 \\
\hline 20 & are committed to \$shared trustworthy values & 3.60 & 1.10 \\
\hline 17 & have integrity & 3.58 & 1.01 \\
\hline 18 & have a passion to achieve strategic goals & 3.53 & 1.09 \\
\hline 19 & are ambitious & 3.45 & 1.01 \\
\hline 11 & have professional astuteness & 3.35 & 1.10 \\
\hline 13 & are energized and motivated & 3.35 & 1.08 \\
\hline 3 & are persistent & 3.30 & 1.05 \\
\hline 15 & have willingness to engage employees & 3.30 & 1.09 \\
\hline 4 & are resilient in facing difficulties and uncertainties & 3.28 & 1.06 \\
\hline 2 & are resolute & 3.25 & 1.08 \\
\hline 12 & are proactive & 3.25 & 1.17 \\
\hline 5 & are brave & 3.23 & 1.23 \\
\hline 8 & adapt and incubate new ideas & 3.20 & 1.24 \\
\hline 1 & have inclusive personality & 3.20 & 1.22 \\
\hline 14 & have a willingness to empower employees & 3.18 & 1.15 \\
\hline 6 & are visionary & 3.13 & 1.18 \\
\hline 9 & have mental agility and creativity & 3.03 & 1.10 \\
\hline 7 & act as champions of innovation & 3.00 & 1.28 \\
\hline \multirow[t]{2}{*}{10} & are world-class warriors & 2.93 & 1.14 \\
\hline & & 3.302 & 1.099 \\
\hline
\end{tabular}

that strategic leaders should have a vision about the direction in which employees should go, inspire the organization, and be brave, visionary, and innovative, which, apparently, were not available to Qatari top-level managers as strategic leaders.

\section{Validating $H 3$ :}

This hypothesis states that there are no statistically significant differences at the significance level of $(\alpha \leq 0.05)$ among respondents in terms of the two concepts of the study (strategic leadership behaviors and strategic leadership characteristics) attributed to their personal and occupational variables.

To measure differences in views among respondents toward the two concepts of the study (strategic leadership practiced behaviors and strategic leaders' characteristics) attributed to their personal and occupational variables, a variance analysis was conducted. To do so, an independent-sample t-test and a one-way between-groups ANOVA were applied. Tables 9-11 display the results of the analysis. 
Table 9. Strategic leadership behaviors and characteristics attributed to the respondents' personal and occupational variables.

\begin{tabular}{|c|c|c|c|c|c|}
\hline \multicolumn{6}{|c|}{ T-Test for Testing the Means of Behavior and Characteristics } \\
\hline \multicolumn{6}{|c|}{ H0: Mean (behavior) = Mean (characteristics) } \\
\hline \multicolumn{6}{|c|}{ Summary Data } \\
\hline & $\mathbf{N}$ & Mean & $\begin{array}{c}\text { Std. } \\
\text { Deviation }\end{array}$ & & $\begin{array}{l}\text { Std. } \\
\text { rror Mean }\end{array}$ \\
\hline Sample 1 & 120.000 & 3.302 & 1.099 & & 0.174 \\
\hline Sample 2 & 120.000 & 3.200 & 1.126 & & 0.178 \\
\hline \multicolumn{6}{|c|}{ Independent Samples Test } \\
\hline & Mean Difference & Std. Error Difference & $\mathrm{t}$ & df & Sig. (2-tailed) \\
\hline $\begin{array}{c}\text { Equal variances } \\
\text { assumed }\end{array}$ & 0.102 & 0.249 & 0.410 & 78.000 & 0.683 \\
\hline \multicolumn{6}{|c|}{ The mean difference is significant at the 0.05 level. } \\
\hline
\end{tabular}

Table 10. ANOVA test for SL behaviors.

\begin{tabular}{|c|c|c|c|c|c|c|}
\hline \multicolumn{7}{|c|}{ ANOVA } \\
\hline & & $\begin{array}{l}\text { Sum of } \\
\text { Squares }\end{array}$ & df & $\begin{array}{l}\text { Mean } \\
\text { Square }\end{array}$ & $\mathrm{F}$ & Sig. \\
\hline \multirow{3}{*}{ Gender } & Between Groups & 5.183 & 80 & 0.199 & 0.662 & 0.821 \\
\hline & Within Groups & 3.917 & 40 & 0.301 & & \\
\hline & Total & 9.100 & 120 & & & \\
\hline \multirow{3}{*}{ Age } & Between Groups & 11.150 & 80 & 0.429 & 0.603 & 0.868 \\
\hline & Within Groups & 9.250 & 40 & 0.712 & & \\
\hline & Total & 20.400 & 120 & & & \\
\hline \multirow{3}{*}{ Years of Service } & Between Groups & 40.150 & 80 & 1.544 & 0.828 & 0.672 \\
\hline & Within Groups & 24.250 & 40 & 1.865 & & \\
\hline & Total & 64.400 & 120 & & & \\
\hline \multirow{3}{*}{ Qualification } & Between Groups & 9.083 & 80 & 0.349 & 0.708 & 0.781 \\
\hline & Within Groups & 6.417 & 40 & 0.494 & & \\
\hline & Total & 15.500 & 120 & & & \\
\hline \multirow{3}{*}{ Job Level } & Between Groups & 39.650 & 80 & 1.525 & 1.844 & 0.124 \\
\hline & Within Groups & 10.750 & 40 & 0.827 & & \\
\hline & Total & 50.400 & 120 & & & \\
\hline
\end{tabular}

The mean difference is significant at the 0.05 level.

Table 11. ANOVA test for SLs' characteristics mean with personal and occupational variables.

\begin{tabular}{|c|c|c|c|c|c|c|}
\hline \multicolumn{7}{|c|}{ ANOVA } \\
\hline & & $\begin{array}{l}\text { Sum of } \\
\text { Squares }\end{array}$ & df & $\begin{array}{c}\text { Mean } \\
\text { Square }\end{array}$ & $\mathbf{F}$ & Sig. \\
\hline \multirow{3}{*}{ Gender } & Between Groups & 6.600 & 86 & 0.236 & 1.037 & 0.501 \\
\hline & Within Groups & 2.500 & 34 & 0.227 & & \\
\hline & Total & 9.100 & 120 & & & \\
\hline
\end{tabular}


Continued

\begin{tabular}{ccccccc}
\hline \multirow{2}{*}{ Age } & Between Groups & 13.567 & 86 & 0.485 & 0.780 & 0.715 \\
& Within Groups & 6.833 & 34 & 0.621 & & \\
& Total & 20.400 & 120 & & & \\
\hline \multirow{3}{*}{ Years of Service } & Between Groups & 47.067 & 86 & 1.681 & 1.067 & 0.479 \\
& Within Groups & 17.333 & 34 & 1.576 & & \\
& Total & 64.400 & 120 & & & \\
\hline \multirow{3}{*}{ Qualification } & Between Groups & 11.500 & 86 & 0.411 & 1.129 & 0.435 \\
& Within Groups & 4.000 & 34 & 0.364 & & \\
& Total & 15.500 & 120 & & & \\
\hline \multirow{2}{*}{ Job Level } & Between Groups & 39.067 & 86 & 1.395 & 1.354 & 0.306 \\
& Within Groups & 11.333 & 34 & 1.030 & & \\
& Total & 50.400 & 120 & & &
\end{tabular}

The mean difference is significant at the 0.05 level.

In summary, the study revealed that there are no statistically significant differences (at the significance level of $\alpha \leq 0.05$ ) among respondents regarding the two main concepts of the study (strategic leadership behaviors and strategic leadership characteristics) attributed to their personal and occupational variables (mean $=3.302$ and 3.200, respectively); standard deviation $=1.099$ and 1.126 , respectively). The value of $P=0.683(P<0.05)$. Therefore, hypothesis H03 is accepted.

To conclude, the findings of this study revealed that Qatari top-level managers are not fully engaged in determining their organizations' strategic direction and do not exercise all strategic leadership behaviors. Instead, they are more engaged in the operational activities of leadership. Further, Qatari top-level managers partially demonstrate SL characteristics, while they should be combatant commanders and champions of innovation and change in the midst of future strategic directions. They must also be creative and visionary, and be willing to empower their employees. Additionally, the study revealed that there are no statistically significant differences (at the significance level of $\alpha \leq 0.05$ ) among respondents toward the two main study concepts (strategic leadership behaviors and strategic leadership characteristics) attributed to their personal and occupational variables.

\section{Conclusion and Implications}

Leading in environments characterized by being chaotic with frequent crisis and surprises, such as the COVID-19 pandemic, with the newly emerging challenges of transworld migrations of capital and labor, cyber employment, and virtual workplaces (see Farazmand, 2007, 2009), demands special strategic leadership (SL) competencies. The aim of this research was to identify a specific SL set of competencies that should be available to strategic leaders and verify their availa- 
bility to top-level public sector managers in the Qatari context. This research revealed that Qatari top-level managers were more engaged in the operational level activities of leadership and less engaged in determining their organizations' strategic direction. They should also be combatant commanders and champions of innovation and change in the midst of future strategic directions of their organizations.

\subsection{Theoretical Implications}

Drawing from the extant strategic leadership literature, this study identified the most "universally common" competency requirements for effective strategic leadership (and/or strategic leaders). Yet, the literature review revealed voluminous mixes and overlaps between and among certain competency components, resulting in difficulty establishing a clear-cut line between one and the other. One example is mixing SL "trait or a characteristic" with "behavior" in the work of Guillot (2003). Another example is using "attitudes" and "skills" interchangeably in the work of Coban, Ozdemir, and Pisapia (2019). To solve this, this research has established a distinction between those competencies that are related to the actual practiced "behaviors" and "characteristics" demonstrated by strategic leaders which can easily be judged by others, on the one side, and those competencies that can mainly be judged by the SLs themselves, such as personal "knowledge" and self "awareness" about a particular issue or subject, and the "skill" level they need to perform a particular task, on the other side. This research has also contributed the scholarship in developing an instrument to measure the availability of SL competencies to top-level managers in different organizational settings.

\subsection{Practical Implications}

On the practical level, it is anticipated that the framework of strategic leadership competencies that this research has developed will significantly contribute to enhancing and building human resources capacities while aimed at helping to achieve National Development Agendas and strategic goals in Qatar and globally. Specifically, the proposed framework can serve as a frame of reference for designing strategic leadership training and development programs and can be used for further development of evidence-based curricula on strategic leadership. In this vein, this research has taken a further step in collecting field-based evidence from the public sector organizations in the State of Qatar to examine the availability of two SL competencies (behaviors and characteristics) to their top-level managers. It is highly recommended that public sector policy and decision makers must bridge competency gaps and deficiencies relating to the top-level public sector managers whom this study explored, to help them lead their organizations more effectively. Specifically, the capacity to lead in the age of recently more chaotic environments demands special attention for building strategic leadership capacity through specialized training programs and workshops aimed at helping top-level executives practice and demonstrate strategic leadership competencies. 


\subsection{Limitations and Future Research Directions}

This research has mainly focused on strategic leadership competences demonstrated by strategic leaders in their organizations. Therefore, SL functions (e.g., the work of Rokonuzzaman and Rahman, 2011), roles (e.g., the work of Burnes, 2004), or responsibilities (e.g., the work of Serfontein and Hough, 2011), were not deemed to be relevant to this research, as these are more related to the organization's structure and design aspects and, by default, are allocated to the SLs.

Empirically, this research has limited its scope to address strategic leaders' behaviors and characteristics, leaving other competency aspects (i.e., knowledge and skills) to further research and discovery endeavors. Further, to avoid the possibility of bias, the findings of this research are based on the perspectives and views of middle-level managers toward their top-level managers, based on their daily interactions and dealings with them. Future research must consider the views of SLs themselves in all KSABO competency components.

\section{Conflicts of Interest}

The author declares no conflict of interest regarding the publication of this paper.

\section{References}

Adair, J. (2009). Not Bosses but Leaders. How to Lead the Way to Success (3rd ed.). London: Kogan Page.

Agyepong, I., Lehmann, U., Rutembemberwa, E., Babich, S., Frimpong, E., Kwamie, A., Olivier, J., Teddy, G., Hwabamungu, B., \& Gilson, L. (2018). Strategic Leadership Capacity Building for Sub-Saharan African Health Systems and Public Health Governance: A Multi-Country Assessment of Essential Competencies and Optimal Design for a Pan African DrPH. Health Policy and Planning, 33, ii35-ii49. https://doi.org/10.1093/heapol/czx162

Appiah-Adu, K., \& Aming, S. (2016). Strategic Thinking and Economic Development: The Case of a Developing Country. In K. Appiah-Adu, \& M. Bawumia (Eds.), Key Determinants of National Development: Historical Perspective and Implication for Developing Economies (pp. 1-10). London: Routledge.

Bass, B. (2007). Executive and Strategic Leadership. International Journal of Business, 12, 34-52. http://www.craig.csufresno.edu/ijb/Volumes/Volume\%2012/V121-3.pdf

Beer, M., \& Eisenstat, R. (2000). The Silent Killers of Strategy Implementation and Learning. Sloan Management Review, 41, 29-40. https://app.mapfre.com/documentacion/publico/i18n/consulta/registro.cmd?id=53089

Boal, K., \& Hooijberg, R. (2000). Strategic Leadership: Moving on. The Leadership Quarterly, 11, 515-549. https://doi.org/10.1016/S1048-9843(00)00057-6 https://www.sciencedirect.com/science/article/pii/S1048984300000576

Bolden, R. (2011). Distributed Leadership in Organizations: A Review of Theory and Research. International Journal of Management Reviews, 13, 251-269. https://doi.org/10.1111/j.1468-2370.2011.00306.x

Burnes, B. (2004). Managing Change: A Strategic Approach to Organizational Dynamics (4th ed.). London: Prentice Hall, Pearson Education. https://books.google.com.qa/books/about/Managing_Change.html?id=9J5Ri4xatEMC 
\&redir_esc $=\mathrm{y}$

Coban, O., Ozdemir, S., \& Pisapia, J. (2019). Top Managers' Organizational Change Management Capacity and Their Strategic Leadership Levels at Ministry of National Education (MoNE). Eurasian Journal of Educational Research, 19, 129-146.

Deshler, R. (2018). Connecting Strategic Thinking to Results: Why Leaders Must See the Practical Side of Ideas. Briarcliff Manor: Academic Management Association. https://playbook.amanet.org/training-articles-connecting-strategic-thinking-results/

Elenkov, D. S., Judge, W., \& Wright, P. (2005). Strategic Leadership and Executive Innovation Influence: An International Multi-Cluster Comparative Study. Strategic Management Journal, 26, 665-682. https://doi.org/10.1002/smj.469

Fairholm, M., \& Fairholm, G. (2009). Understanding Leadership Perspectives: Theoretical and Practical Approaches. New York, NY: Springer Science \& Business Media. https://doi.org/10.1007/978-0-387-84902-7

Farazmand, A. (2007). Strategic Public Personnel Administration Building and Managing Human Capital for the 21st Century. Westport: Greenwood Publishing Group.

Farazmand, A. (2009). Building Administrative Capacity for the Age of Rapid Globalization: A Modest Prescription for the Twenty-First Century. Public Administration Review, 69, 1007-1020. https://doi.org/10.1111/j.1540-6210.2009.02054.x

Fasial, A., \& Ayub, N. (2018). Leadership Competencies of Physicians Working in Public and Private Sector Hospitals of Karachi. Pakistan Business Review, 20, 656-675. https://www.journals.iobmresearch.com/index.php/PBR/article/view/2124

Gerras, S. (2010). Strategic Leadership Primer (3rd ed.). Carlisle, PA: US Army War College Barracks.

Goldman, E. (2012). Leadership Practices that Encourages Strategic Thinking. Journal of Strategy and Management, 5, 25-40. https://doi.org/10.1108/17554251211200437

Goldman, E., Scott, A., \& Follman, J. (2015). Organizational Practices to Develop Strategic Thinking. Journal of Strategy and Management, 8, 155-175. https://doi.org/10.1108/JSMA-01-2015-0003

Graetz, F. (2012). Strategic Thinking versus Strategic Planning: Towards Understanding the Complementarities. Management Decision, 40, 456-462.

https://doi.org/10.1108/00251740210430434

Guillot, W. (2003). Strategic Leadership: Defining the Challenge. Air \& Space Power Journal, 17, 67-75.

https://www.airuniversity.af.edu/Portals/10/ASPJ/journals/Volume-17_Issue-1-4/win0 3.pdf

Gupta, A. K., \& Govindarajan, V. (1984). Business Unit Strategy, Managerial Characteristics and Business Unit Effectiveness at Strategy Implementation. Academy of Management Journal, 27, 25-41.

Hagen, A., Hassan, M., \& Amin, S. (1998). Critical Strategic Leadership Components: An Empirical Investigation. SAM Advanced Management Journal, 63, 39-44.

Hambrick, D., \& Mason, P. (1984). Upper Echelons: The Organization as a Reflection of Its Top Managers. Academy of Management Review, 9, 193-206. https://doi.org/10.5465/amr.1984.4277628

Heinen, M., Oostveen, C., Peters, J., Vermeulen, H., \& Huis, A. (2019). An Integrative Review of Leadership Competencies and Attributes in Advanced Nursing Practice. Journal of Advanced Nursing, 75, 2378-2392. https://doi.org/10.1111/jan.14092 https://onlinelibrary.wiley.com/doi/epdf/10.1111/jan.14092

Hirschi, G., \& Jones, M. (2009). Affects of Strategic Leadership on Business Success: A 
Cross-Cultural Analysis from a Resource Based View. MIBES Transactions, 3, 1-18. https://ro.uow.edu.au/buspapers/450

Hitt, M., Ireland, R., \& Hoskisson, R. (1995). Strategic Management: Competitiveness and Globalization Concepts. St. Paul, MN: West Publishing Company.

Hosmer, L. (1982). The Importance of Strategic Leadership. Journal of Business Strategy, 3, 47-57. https://doi.org/10.1108/eb038966

Huang, H. C. (2009). Designing a Knowledge-Based System for Strategic Planning: A Balanced Scorecard Perspective. Expert Systems with Applications, 36, 209-218. https://doi.org/10.1016/j.eswa.2007.09.046

Ireland, R., \& Hitt, M. (1999). Achieving and Maintaining Strategic Competitiveness in the 21st Century: The Role of Strategic Leadership. Academy of Management Executive, 13, 43-57. https://doi.org/10.5465/ame.1999.1567311

Irtaimeh, H. (2018). Impact of Strategic Leadership Competencies on Enhancing Core Competencies in Organizations: Applied Study on Al Manaseer Group for Industrial \& Trading. Modern Applied Science, 12, 169-180. https://doi.org/10.5539/mas.v12n11p169

Javidan, M. (1998). Core Competence: What Does It Mean in Practice. Long Range Planning, 31, 60-71. https://doi.org/10.1016/S0024-6301(97)00091-5

Kaplan, R., \& Norton, D. (1992). The Balanced Scorecard-Measures That Drive Performance. Harvard Business Review, January/February Issue, 71-80. https://hbr.org/1992/01/the-balanced-scorecard-measures-that-drive-performance-2

Liedtka, J., \& Rosenblum, J. (1998). Teaching Strategy as Design: A Report from the Field. Journal of Management Education, 22, 285-303. https://doi.org/10.1177\%2F105256299802200303

Maarten, V. B., \& Mikhail, G. (2010). Building Strategic Leadership Competencies: The Case of UNILIVER. International Journal of Leadership Studies, 5, 317-332. https://issuu.com/maartenvanbeek/docs/international_journal_of_leadership

Mapetere, D., Mavhiki, S., Nyamwanza, T., Sikomwe, S., \& Mhonde, C. (2012). Strategic Role of Leadership in Strategy Implementation in Zimbabwe's State Owned Enterprises. International Journal of Business and Social Science, 3, 271-276. http://ijbssnet.com/journals/Vol_3_No_16_Special_Issue_August_2012/29.pdf

Marshall, S. (2019). What Does Future Look Like for Strategic Leadership? In S. Marshall, (Ed.), Strategic Leadership of Change in Higher Education: What's New (2nd ed.)? Abingdon-on-Thames: Routledge. https://doi.org/10.4324/9780429468766-13 https://books.google.com.qa/books?hl=en\&lr=\&id=TuOLDwAAQBAJ\&oi=fnd\&pg=P T258\&dq=strategic+leadership+competency\&ots=LECDpLVvl1\&sig=egWuq4AhVCv QWKbrFbP2bH4tK4Q\&redir_esc=y\#v=onepage\&q=strategic\%20leadership\%20compe tency\&f=false

Mintzberg, H. (1994). The Rise and Fall of Strategic Planning. Harvard Business Review, January/February Issue, 107-114. https://hbr.org/1994/01/the-fall-and-rise-of-strategic-planning

Norzailan, Z., Othman, R., \& Ishizaki, H. (2016). Strategic Leadership Competencies: What Is It and How to Develop it? Industrial and Commercial Training, 48, 394-399. https://doi.org/10.1108/ICT-04-2016-0020

Norzailan, Z., Yusof, S. M., \& Othman, R. (2016). Developing Strategic Leadership Competencies. Journal of Advanced Management Science, 4, 66-71.

https://doi.org/10.12720/joams.4.1.66-71

http://www.joams.com/uploadfile/2014/1008/20141008051224975.pdf 
Pisapia, J., Reyes-Guerra, D., \& Coukos-Semmel, E. (2005). Developing the Leader's Strategic Mindset: Establishing the Measures. Kravis Leadership Institute. Leadership Review, 5, 41-68.

https://www.researchgate.net/profile/Daniel_Reyes-Guerra/publication/252809369_De velop-

ing_the_Leader's_Strategic_Mindset_Establishing_the_Measures/links/556e78d108aec2 268308c6ad/Developing-the-Leaders-Strategic-Mindset-Establishing-the-Measures.pdf

Rokonuzzaman, M., \& Rahman, M. (2011). Workplace Harassment and Productivity: A Comprehensive Role of Strategic Leadership. Journal of General Education, 1, 41-49. https://www.academia.edu/35181611/Workplace_Harassment_and_Productivity_A_C omprehensive_Role_of_Strategic_Leadership

Ruben, B. (2019). An Overview of the Leadership Competency Framework. In R. Gigliotti (Ed.), Competencies for Effective Leadership (pp. 19-28). Bingley: Emerald Publishing Limited. https://doi.org/10.1108/978-1-78973-255-920191001

Sashkin, M. (1992). Strategic Leader Competencies. In R. Phillips, \& J. Hunt, Eds., Strategic Leadership: A Multi-Organizational-Level Perspective (pp. 139-160). Westport, CT: Quorum Books.

https://www.amazon.com/Strategic-Leadership-Multiorganizational-Level-PerspectiveStudies/dp/0899307566

Schoemaker, P., Krupp, S., \& Howland, S. (2013). Strategic Leadership: The Essential Skills. Harvard Business Review, January/February Issue, 1-5. https://hbr.org/2013/01/strategic-leadership-the-esssential-skills

Sebnem, A., Diken, A., \& Sendogdu, A. (2011). Investigation of the Effects of Strategic Leadership on Strategic Change and Innovativeness of SMEs in a Perceived Environmental Uncertainty. Procedia-Social and Behavioral Sciences, 24, 627-642. https://doi.org/10.1016/j.sbspro.2011.09.009

Serfontein, K., \& Hough, J. (2011). Nature of the Relationship between Strategic Leadership, Operational Strategy and Organizational Performance. South African Journal of Economic and Management Sciences, 14, 393-406. https://doi.org/10.4102/sajems.v14i4.21

Shao, Z. (2019). Interaction Effect of Strategic Leadership Behaviors and Organizational Culture on IS-Business Strategic Alignment and Enterprise Systems Assimilation. International Journal of Information Management, 44, 96-108. https://doi.org/10.1016/j.ijinfomgt.2018.09.010

Shao, Z., Feng, Y., \& Hu, Q. (2017). Impact of Top Management Leadership Styles on ERP Assimilation and the Role of Organizational Learning. Information \& Management, 54, 902-919. https://doi.org/10.1016/j.im.2017.01.005

Silva, L., Figueroa, E., \& González-Reinhart, J. (2007). Interpreting IS Alignment: A Multiple Case Study in Professional Organizations. Information and Organization, 17, 232-265. https://doi.org/10.1016/j.infoandorg.2007.08.001

Sotarauta, M. (2005). Shared Leadership and Dynamic Capabilities in Regional Development. In I. Sagan \& H. Halkier (Eds.), Regionalism Contested: Institution, Society and Governance (pp. 53-72). Cornwall: Urban and Regional Planning and Development Series.

Stigter, M., \& Cooper, C. (2015). Solving the Strategy Delusion: Mobilizing People and Realizing Distinctive Strategies. London: Palgrave Macmillan. https://doi.org/10.1057/9781137394699

Vera, D., \& Crossan, M. (2004). Strategic Leadership and Organizational Learning. Academy of Management Review, 29, 222-240.

https://doi.org/10.5465/amr.2004.12736080 
Weiler, J., \& Dohlen, H. (2019). Ready to Lead: Using Competency Models to Build and Assess Leadership Competency in Pre-Service School Leaders. In K. K. Winter, H. H. Pinter, \& M. K. Watson (Eds.), Performance-Based Assessment in 21st Century Teacher Education (pp. 184-204). Hershey, PA: IGI Global. https://doi.org/10.4018/978-1-5225-8353-0.ch008

Wong, L., Gerras, S., Kidd, W., Pricone, R., \& Swengros, R. (2003). Strategic Leadership Competencies. Report No. ADA631451, Carlisle, PA: Strategic Studies Institute. https://apps.dtic.mil/dtic/tr/fulltext/u2/a631451.pdf 